\title{
Lean Manufacturing Model of Waste Reduction Using Standardized Work to Reduce the Defect Rate in Textile MSEs
}

\author{
Nicole Barrientos-Ramos ${ }^{1}$, Luz Tapia-Cayetano ${ }^{1}$, Fernando Maradiegue-Tuesta, $\mathrm{Mg}^{1}$ and Carlos Raymundo, $\mathrm{PhD}^{2}$ \\ ${ }^{1}$ Ingeniería Industrial, Universidad Peruana de Ciencias Aplicadas, Lima, Perú. u201512779@upc.edu.pe, \\ u201512544@upc.edu.pe,fmaradie@upc.edu.pe \\ ${ }^{2}$ Dirección de Investigación, Universidad Peruana de Ciencias Aplicadas, Lima, Perú, carlos.raymundo@upc.edu.pe
}

\begin{abstract}
The textile industry currently represents $7.2 \%$ of the manufacturing companies' GDP. However, it has experienced severe sales volatility owing to the high competitiveness, primarily mainly from Southeast Asian countries. Low productivity, process variability, operating cost overruns or long lead times are the main causes of the sector gap that must be attacked. Thus, this research is aims to contribute to the textile industry with methodologies and tools to gain a competitive advantage and reduce its operating cost overruns. We analyzed a real case study applied to a company called TEXTIL S.AC., following the implementation of combined work to integrate labor, work method, and machines to reduce the manufacturing cycle time by 300 seconds and, thus, waste such as defective products that generate expenses for the company. The results of the implementation and validation through process simulation showed an $8 \%$ reduction in the defect rate and a $32 \%$ improvement in the lead times.
\end{abstract}

Keywords-Waste reduction, Lean Manufacturing, Standard work, Textile industry, $5 S^{\prime}$ 's in textile industry.

\section{INTRODUCTION}

The textile industry is an important source of income and employment for many developing countries. In the last decade, a significant increase in the textile and clothing trade has been observed among Asian countries. However, this trade is skewed toward a handful of countries in East and South Asia. Similarly, China (together with Hong Kong) dominates this trade with a majority share of up to $65 \%$. Other significant suppliers are India, South Korea, and Japan, with a 7\%, 5\%, and $4 \%$ share, respectively [1]. The greatest changes in the textile industry occurred in the 1960 s, following the rapid emergence of new production centers in the Asian region. However, the industrialized countries managed to maintain their competitive advantage due to the production equipment modernization [2]. In Peru, the textile sector represents $7.2 \%$ of the manufacturing companies' GDP, according to the information extracted from Produce (Ministry of Production) [3]. Thus, the textile industry, having a strong impact on the economy, is a relevant sector in the national economic activity and a significant national employment promoter that generates around 422 thousand direct jobs annually.

However, in Peru, the textile industry faces difficult times, evidenced through a decrease in the sales, both domestically and overseas. Facho [4] states that it is more complicated to expand business and close orders because the main clothing brands have relocated to Southeast Asia, carrying with them significant production volumes at low prices with which the national textile sector cannot compete. In part, this variation is owing to the manufacturing production and its divisions. Thus, we must investigate and tackle the main causes that lead customers to choose Asian garments over domestic products. After analyzing the national market, we identified the potential causes that lead to sales variations, such as high lead times or excessive amount of reprocessed garments. In view of this, several authors have studied the textile industry to seek solutions to the main issues. They state that to achieve successful business practices, both medium and small-sized enterprises should use effective strategies such as Lean tools in a given process to face the changing requirements of their customers and the business environment [5]. In production systems, defective products are one of the wastes with the greatest negative impact on delivery times, cost, quality, and non-compliance with standards. However, according to various studies, companies implementing tools such as Value Stream Mapping (VSM), 5S, Kanban and Total Productive Maintenance (TPM) manage to reduce not only the number of defective products but also the cycle time of garment production and the costs incurred in, given that these solutions are appropriate to deal with wasterelated problems [6] [7].

Based on the aforementioned, the purpose of this research is to provide a Lean Manufacturing model for waste reduction to tackle the Peruvian textile industry problems. We intend to show that the engineering tools can achieve significant and high-impact changes not only in the company under study but also in all the Peruvian textile companies. The methodology of the combined work under the Lean approach aims to improve productivity, thus reducing operating cost overruns by integrating all the company's resources and identifying those non-value-added manual activities. The goal is to achieve great results with low investment, given that the sector mostly counts on micro and small enterprises (MSEs) that monopolize a large part of the market.

This document will be divided into four sections for conducting the research development. The first section will present the literature review or state of the art, consisting in an exhaustive review of studies previously conducted and quoting experts in the field. The second section will detail the contribution because of previous cases reviewed for a specific

\footnotetext{
Digital Object Identifier (DOI):

http://dx.doi.org/10.18687/LACCEI2020.1.1.356

ISBN: 978-958-52071-4-1 ISSN: 2414-6390
}

18th LACCEI International Multi-Conference for Engineering, Education, and Technology: "Engineering, Integration, and Alliances for a Sustainable Development" "Hemispheric Cooperation for Competitiveness and Prosperity on a Knowledge-Based Economy", July 27-31, 2020, Virtual Edition. 
case that can be replicated throughout the industry, highlighting the methodology and tools used to deal with the problem. The third section will focus on the result validation using a simulation and show the quantitative data that validates the improvement proposal. The final section will discuss the development of this article.

\section{StATE OF THE ART}

\section{A. Waste reduction model in the textile industry}

The word "waste" usually defines something around us that should be recycled, reused, reduced, or even eliminated, if possible. Every day a large amount of waste is generated in the textile industries from excessive lead times, large amounts of defective products, overproduction, and so on. The term "zero waste" (ZW) is continually encouraging both producers and consumers to adopt sustainable approaches for reducing their waste and helping them make the world more sustainable. Therefore, several authors highlighted the importance of a proper waste management system, proposing waste reduction models to achieve $\mathrm{ZW}$ manufacturing, fluctuations in the work-in-process (WIP) inventory under controlled standards, and optimization techniques that reduce cycle time in the textile industries, such as ant colony optimization algorithms [8] [9] [10] [11]. The authors' analysis is based on collecting information on lead times, amount of WIP inventory, or production line defects and implementing various Lean tools to directly attack the root causes of the mentioned problems. Thus, they achieved an optimal flow with a machinery work sequencing based on a standardized model that reduced the lead time and the percentage of defects up to $10 \%$. [11][12][13].

Results analysis shows cycle time values well below the most critical level, after using a hybrid flow shop scheduling. Moreover, a time reduction of up to $10 \%$ was achieved after implementing the standardized work sequencing in the most critical processes of the production line.

\section{B. Lean manufacturing applied to waste reduction models in the textile industry \\ Several studies of the textile industry have aimed at} increasing its competitiveness. The authors agree that small and medium-sized enterprises (SMEs) are often under pressure owing to a difficult financial situation and must increase effectiveness to maintain their competitive advantage. Thus, they argued that Lean tool implementation is the best method to address the supply chain management and the industry's production environment to improve its productivity $[12][13][14]$. They implemented the five principles that define the Lean concept: (1) defining value, (2) mapping the value stream, (3) creating flow, (4) using a pull system, and (5) pursuing perfection, in addition to the definition of waste and the increase in production and efficiency. They also consider the theory of constraints as an efficient tool for resource optimization and material flow improvement, achieving an increase in order fulfillment by $30 \%$ and a decrease in WIP by
$80 \%$ [12] [13]. Likewise, studies agree that for reducing waste and optimizing production, the combination of Lean Manufacturing (LM) standards with tools such as VSM, 5S, TPM, or SMED are among the most effective in large industries. The main results were the reduction of machine stoppage frequency, waste, repetitive steps, quality improvement, and, above all, sustainable business practices. $[9][10][11]$. In general terms, one of the main benefits and results of Lean tool implementation in the textile industry are the improvement in production line efficiency, inventory reduction, improved production process, reduction of defective products, and equipment performance [14] [15].

\section{Standardized work applied to waste reduction models in the textile industry}

Authors agree that companies must follow a methodology intended to counteract situations, such as the manufacturing process variability, the lack of a detailed sequence of work procedures, and the great product diversity, through the standardized work method [16] [17]. The action-research methodology of standardized work can be implemented in a 5stage cycle: 1) Diagnosis, which is understanding how the company works and what should be done; 2) Action planning, which consists of proposing a table combining the information on the process times and their visual representation; 3) Standard action table, which provides standard operation times for a work section; 4) Evaluation; and 5) learning specifications. The main results, such as the increased part production capacity per worktable allowed, were shown comparing the current state with the improved one. This was $25 \%$ higher than the initial takt time. These results obtained in the workshop, where the standardized work was implemented, allowed to determine the work station capacity, a better visual representation of the operations and the cycle time, which provided benefits to the process, increasing its flexibility, reducing manufacturing errors, and decreasing the process variability [16] [17]. Based on the implementation and analysis of the authors, by integrating standardized work with information systems, we managed to improve the effectiveness and precision of standardized times by $38 \%$ [17] [18], making the method appropriate for waste reduction in the industry.

\section{Lean manufacturing and standardized work applied to waste reduction models in the textile industry.}

Many organizations struggle to implement Lean tools, especially in SMEs, which deal with scarce resources or complex processes [19]. Therefore, some authors developed research on the Lean tool applicability in various industries. Many small-scale manufacturing companies lack a system for guaranteeing that they will deliver a quality product to their customers, and often, their operation is considered inefficient [19]. An interesting method based on quality, time and flexibility KPIs, among others, was used to identify the most appropriate Lean tool in a MSE [20] [21]. Likewise, to achieve Lean tool applicability in MSEs, we must analyze the 
different types of waste and identify which process tools are to be applied based on the literature and the applicability review in different case studies [11] [18]. In this regard, the implementation of LM standards with tools such as VSM, 5S, TPM, SMED, and standardized work has achieved waste reduction and production optimization. The main results were a reduction in machine stoppage frequency, waste, repetitive steps, as well as an improvement in quality and, above all, sustainable business practices. This analysis was performed to help companies adopt the most appropriate tool for their purpose and specific goals, thus eliminating difficulties in identifying the best strategy [11][19][21].

\section{CONTRIBUtION}

\section{A. Rationale}

The main current problems experienced by the textile sector are, as already mentioned, low productivity, process variability, operating cost overruns, and long lead times, among others, giving rise to the sales gap that affects the textile industries. Thus, we proposed a production model based on standardized work and Lean tools to attack the variability causes in the textile sector.

Based on the typologies described, we found that standardized work is the most effective tool in terms of reduction of times and number of defects caused in a manufacturing company [16] [17]. We showed that using a standard work combination sheet in a workshop under study increased the workstation's takt time by $25 \%$. Another key tool is the $5 \mathrm{~S}$ method, which, applied in a case study, reduced up to $80 \%$ the waste costs over a 3 -year period [22]. To complete the research scope, we sought a third tool that, in conjunction with standardized work and 5S's, would provide support to achieve significant organizational results. Thus, we used preventive maintenance, as previous research shows results of up to $98.5 \%$ machine availability and $85.5 \%$ machine reliability, entailing an increase in productivity of up to $65 \%$ [21]. According to the literature review analysis, the proper integration of these three tools is expected to achieve relevant benefits in the present case study.

\section{B. Proposed model}

Exhibited in Fig. 1 is the proposed waste reduction model based on the analysis described above, to outline the stages to be followed for its implementation.

\section{Model components}

In this section, we will detail the components of the solution design and proposal.

\section{1) Phase 1: 5S's implementation}

To create an orderly environment for implementing the other tools, we used 5S, following these steps (Fig. 2):

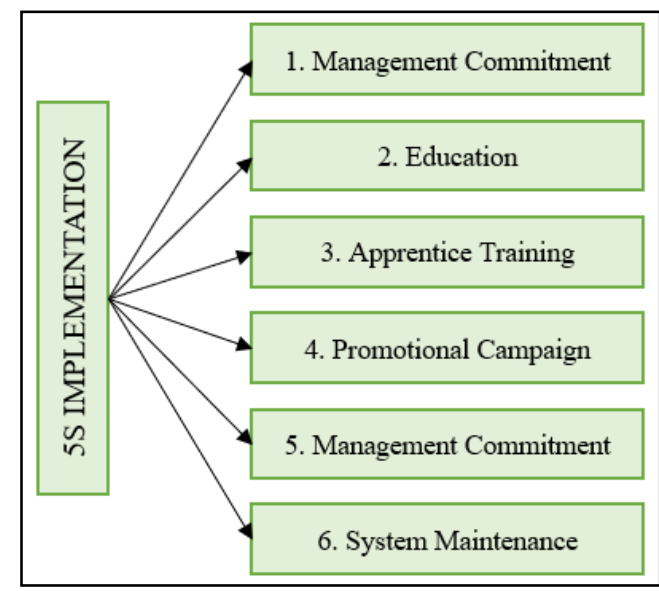

Fig. 2 5S’s steps

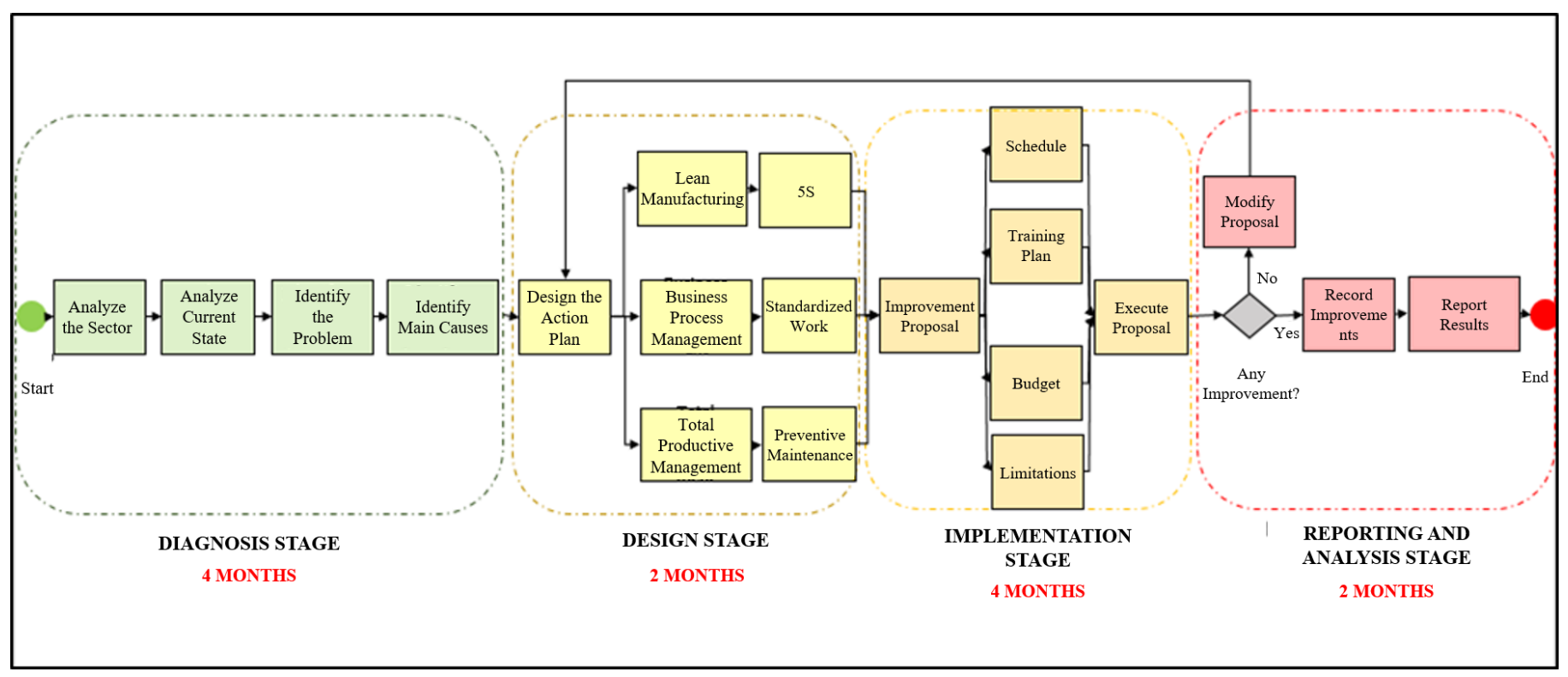

Fig. 1 Proposed model

$18^{\text {th }}$ LACCEI International Multi-Conference for Engineering, Education, and Technology: "Engineering, Integration, and Alliances for a Sustainable Development" "Hemispheric Cooperation for Competitiveness and Prosperity on a Knowledge-Based Economy", 29-31 July 2020, Buenos Aires, Argentina. 
- Sort: This first concept is used to eliminate unwanted or unnecessary items.

- Set in Order: The second "S" is used for an optimal distribution of the work area items.

- Shine: An evaluation checklist was developed for the cleaning inspections to be performed every morning.

- Standardize: Standardization is used to integrate and maintain the first three "S's" into the routine work.

- Sustain: Self-discipline is crucial to ensure that any implementation will last over time and continue to improve the state of a given process.

\section{2) Phase 2: Standardized work}

The following activities were considered to implement the standardized work:

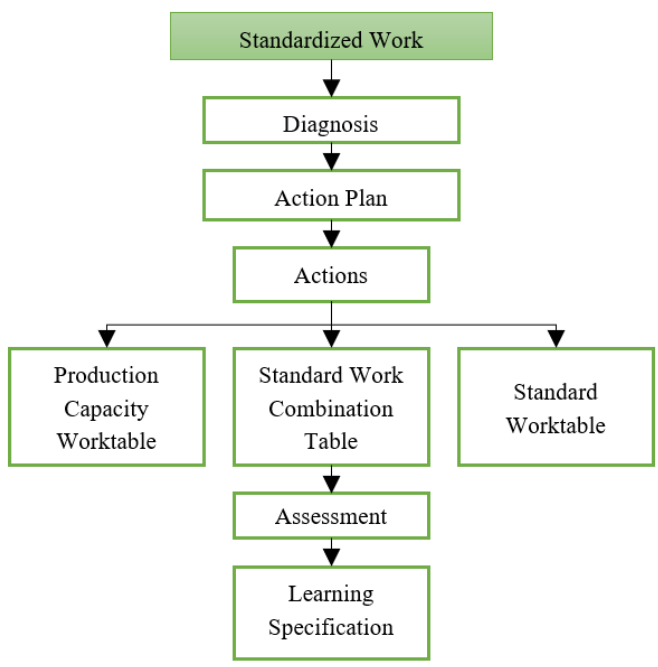

Fig. 3 Standardized work phases
This model depicted two different ways, in terms of sequence, for manufacturing polo shirts. To standardize the process, the work sequence that takes the least time to document the procedure was selected and rated "standard" (Fig.4).

\section{3) Phase 3: Preventive Maintenance}

To decrease the number of equipment failures or breakdowns during the production process, we propose a preventive maintenance management system consisting of the following steps.

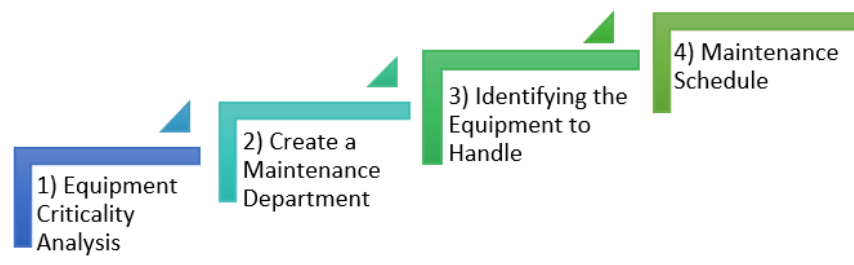

Fig. 5 Preventive maintenance activities

\section{Implementation process}

To ensure the correct implementation of the above tools, we used a process diagram, which summarizes the key phases to be considered for ensuring an optimal implementation and the expected results (See Figure 6).

\begin{tabular}{|c|c|c|c|c|c|c|c|c|c|c|}
\hline \multicolumn{11}{|c|}{ STANDARD WORK COMBINATION SHEET } \\
\hline \multicolumn{3}{|c|}{ Station: Polo Shirt Manufacturing } & \multirow{2}{*}{\multicolumn{8}{|c|}{$\begin{array}{c}\text { Date: } 08-10-2019 \\
\text { Operating Time (Sec) }\end{array}$}} \\
\hline \multirow{2}{*}{ No } & \multirow{2}{*}{ Description } & \multirow{2}{*}{ Time } & & & & & & & & \\
\hline & & & 50 & 100 & 150 & 200 & 250 & 300 & 350 & 400 \\
\hline 1 & $\begin{array}{c}\text { Matching Front and Back } \\
\text { Shoulder Seams }\end{array}$ & 28 & & & & & & & & \\
\hline 2 & Neck Closing & 108 & & & & & & & & \\
\hline 3 & Attach Size/Wash Label & 15 & & & & & & & & \\
\hline 4 & Shoulder Lockstitch & 35 & & & & & & & & \\
\hline 5 & Sleeve Basting & 29 & & & & & & & & \\
\hline 6 & Sleeve Joint & 42 & & & & & & & & \\
\hline 7 & Close Side Seams & 107 & & & & & & & & \\
\hline 8 & Polo Shirt Basting & 24 & & & & & & & & \\
\hline & Total Time & 359 & $\mathrm{Ma}$ & & & tomat & --- & & lacem & \\
\hline
\end{tabular}

Fig. 4 Activities after standardization 


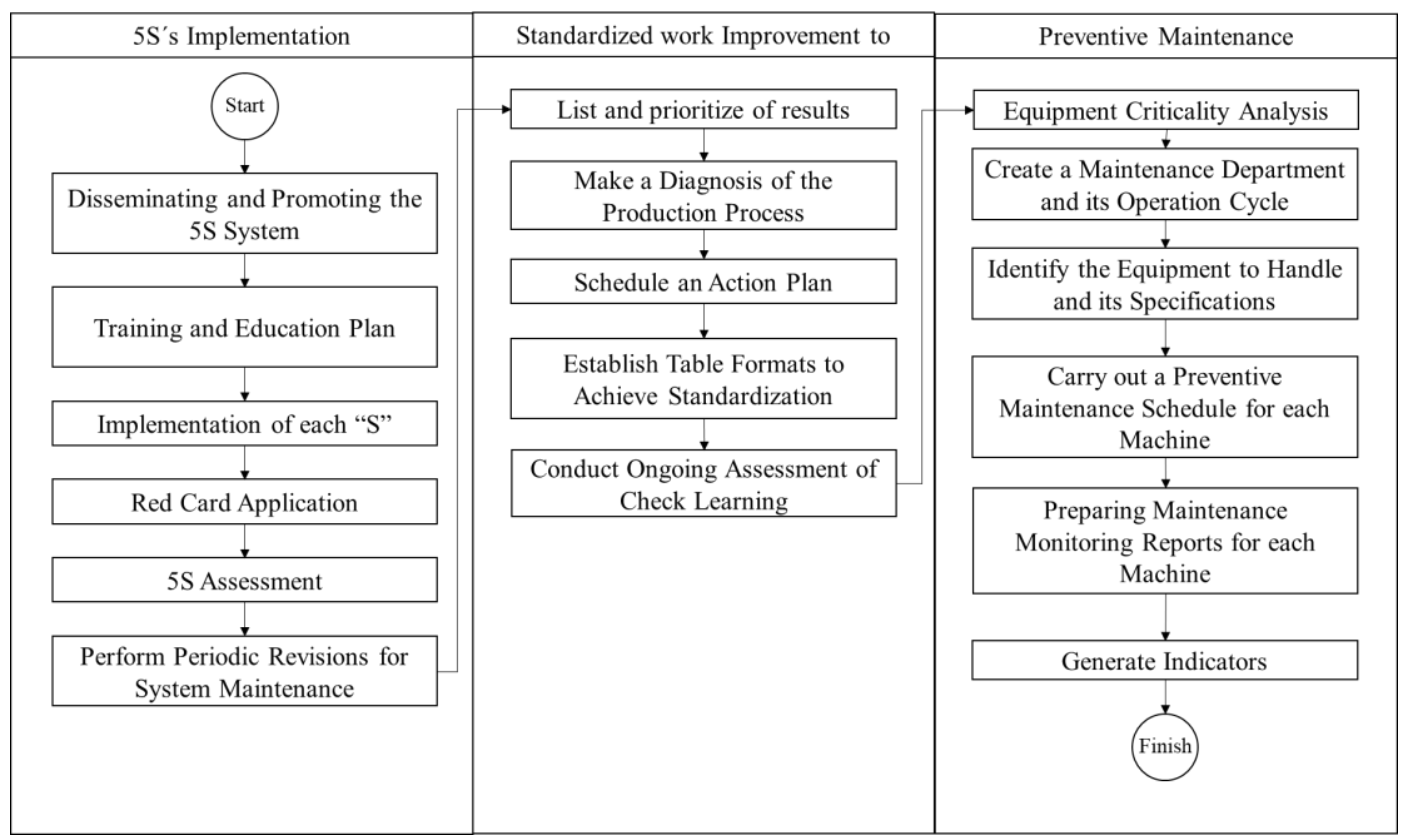

Fig. 6 Implementation process

\section{E. Indicators}

This section shows the indicators associated with the improvement proposal that will serve as a starting point for validation.

1) Defective products: The number of products with some error of the entire polo shirt production.

$$
\frac{\text { Units of defective products }}{\text { Total production }} \times 100
$$

2) Cleanliness and order revision: Evaluation forms are used to verify whether the area complies with the expected order.

$$
\frac{\text { Score obtained }}{\text { Total score }} \times 100
$$

3) Rework level: Total number of defective units that have been reworked for saving the garment and generated extra costs.

$$
\frac{\text { Reworked units }}{\text { Total units }} \times 100
$$

\section{VALIDATION}

\section{A. Scenario}

To develop the research, we conducted a study in a Peruvian textile company called TEXTIL S.AC. The analysis covers data from year 2018, which showed that the percentage of defective products exceeded the baseline (8\%). In addition, the lack of standardization in the processes was clearly evidenced by the increase in manufacturing time and constant rework. This study showed that the defective products decreased the company's revenue and generated variability in the manufacturing process.

\section{B. Initial diagnosis results}

The preliminary analysis made in this case study provided quantitative information on the diagnosis made and showed that the percentage of defective products exceeded the baseline limit of $8 \%$ (see Figure 7).

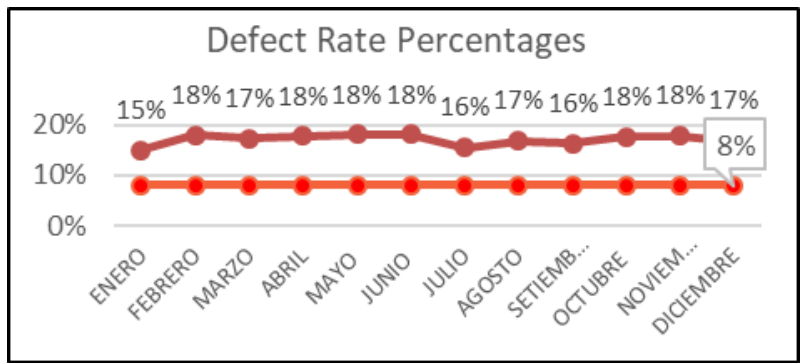

Fig. 7 Defect rate percentages

\section{Implementation of the proposed model}

To address the main problem of variability in the textile line manufacturing process, we initially created a tree diagram (see Figure 8) where we placed the main root causes that will be attacked using the three tools that, collectively, are aimed at making improvements sustainable over time. 


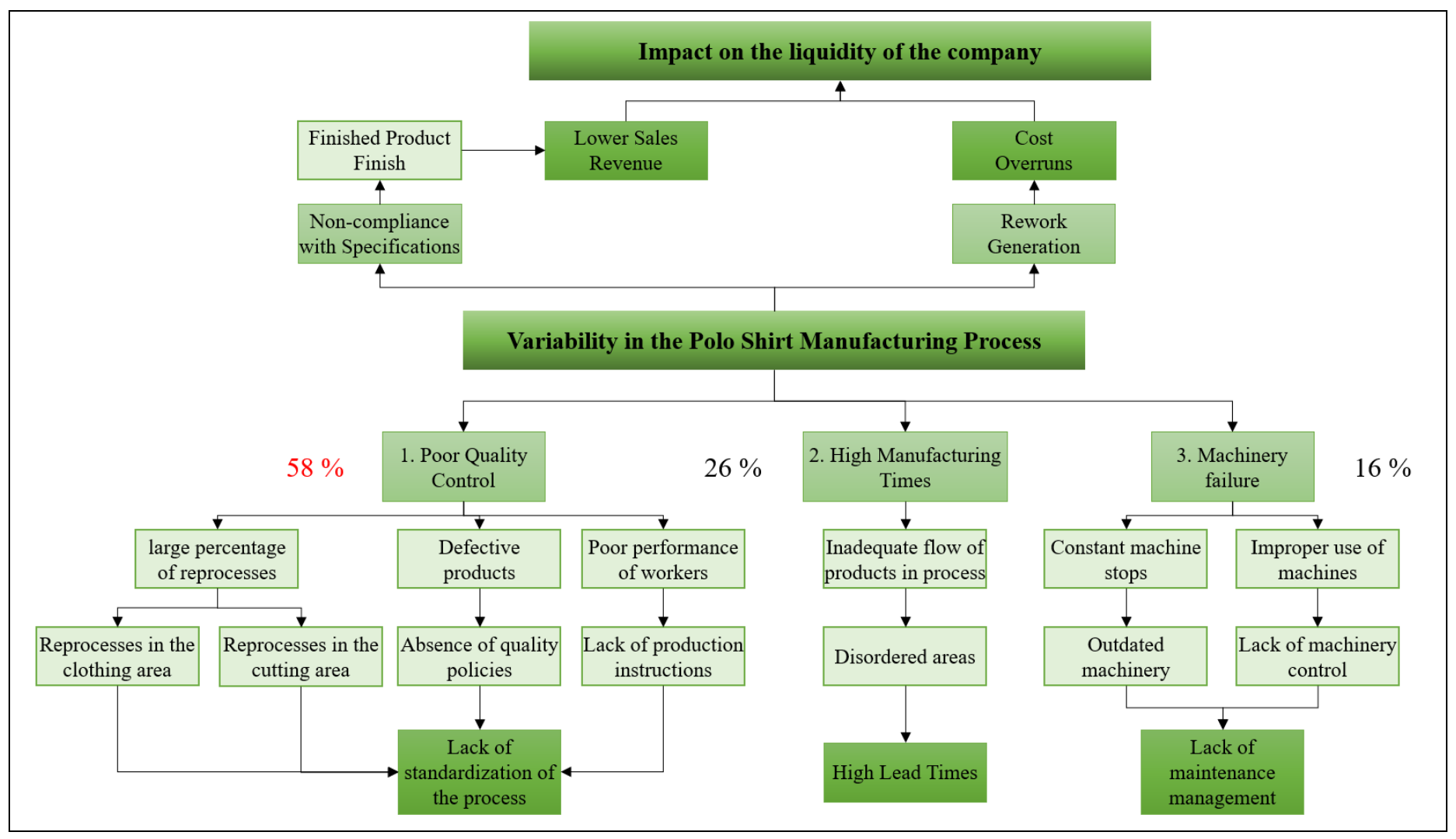

Fig. 8 Root cause tree

The first tool proposed is to implement the $5 \mathrm{~S}$ in the cutting area, to improve the flow of the pieces provided to the sewing area and avoid delays between one area and another. For the $5 \mathrm{~S}$ implementation, actions described in Table I were considered.

TABLE I

IMPLEMENTATION ACTIONS

\begin{tabular}{|c|c|c|}
\hline No. & Action & Recommendation \\
\hline 1 & $\begin{array}{l}\text { Establishment of the } \\
\text { Board of Directors }\end{array}$ & $\begin{array}{l}\text { - Having the team formed } \\
\text { - Take before and after pictures } \\
\text { - Set the process measurement } \\
\text { indicators }\end{array}$ \\
\hline 2 & $\begin{array}{l}\text { Implementation } \\
\text { Development }\end{array}$ & $\begin{array}{l}\text { - 5S Implementation (sort, set in } \\
\text { order, shine, standardize, and } \\
\text { sustain) } \\
\text { - Recording of actions, images, } \\
\text { goal achievement } \\
\text { - Analysis and improvement plan } \\
\text { - Standardization }\end{array}$ \\
\hline 3 & Results & $\begin{array}{l}\text { - Communicate to the whole team } \\
\text { - Feedback } \\
\text { - Lessons learned }\end{array}$ \\
\hline 4 & $\begin{array}{l}\text { Implementation to } \\
\text { Other Areas }\end{array}$ & $\begin{array}{l}\text { - Propose actions based on the } \\
\text { pilot plan in the cutting area } \\
\text { - Benefit from the knowledge } \\
\text { acquired }\end{array}$ \\
\hline 5 & $\begin{array}{l}\text { Continuous } \\
\text { Improvement }\end{array}$ & $\begin{array}{l}\text { - Periodic revision } \\
\text { - Indicator monitoring } \\
\text { - Further training } \\
\text { - Suggestions from employees }\end{array}$ \\
\hline
\end{tabular}

The study also proposes the implementation of standardized work, whose main goal is to reduce variability and achieve a basis for improvement activities [23]. The polo shirt manufacturing process does not follow a determined sequence; therefore, the manufacturing times vary from one production to another, depending also on the operator. The current average time for polo shirt manufacturing is 8.5 minutes and consists of 11 activities, which can be seen in the standard work combination sheet (See Figure 9).

\begin{tabular}{|c|c|c|c|c|c|c|c|c|c|c|c|c|}
\hline \multicolumn{13}{|c|}{ STANDARD WORK COMBINATION SHEET } \\
\hline \multicolumn{3}{|c|}{ Station: Polo Shirt Manufacturing } & \multirow{2}{*}{\multicolumn{10}{|c|}{$\begin{array}{r}\text { Date: } 08-10-2019 \\
\text { Operating Time (Sec) }\end{array}$}} \\
\hline \multirow{2}{*}{ No } & \multirow{2}{*}{ Description } & \multirow{2}{*}{ Time } & & & & & & & & & & \\
\hline & & & 50 & 100 & 150 & 200 & 250 & 300 & 350 & 400 & 450 & 500 \\
\hline 1 & Neck Closing & 108 & & & & & & & & & & \\
\hline 2 & $\begin{array}{l}\text { Collar Joint with } \\
\text { Front }\end{array}$ & 12 & & & & & & & & & & \\
\hline 3 & Attach Back Piece & 20 & & & 4 & & & & & & & \\
\hline 4 & Attach Size & 15 & & & & & & & & & & \\
\hline 5 & Join Shoulders & 28 & & & & & & & & & & \\
\hline 6 & Attach Collar & 55 & & & & & 4 & & & & & \\
\hline 7 & Shoulder Lockstitch & 38 & & & & & & & & & & \\
\hline 8 & Make Sleeve Cuffs & 29 & & & & & & & & & & \\
\hline 9 & Sleeve Joint & 42 & & & & & & & & & & \\
\hline 10 & Close Side Seams & 107 & & & & & & & & & & \\
\hline 11 & Polo Shirt Basting & 24 & & & & & & & & & & $4^{n}$ \\
\hline & Total Time & 478 & & nual & & & we & itic & & isplac & ement & $\sim$ \\
\hline
\end{tabular}

Fig. 9 Root cause tree 
To validate the improvement proposed through this study, the implementation was simulated and compared with the current state. The software used is validated with experts and its use is essential to achieve results.

\section{System simulation}

The manufacturing process begins with the piece arrival: front, back, collar, and sleeves. First, the front joint is made and, then, the collar frame and its union. Then the shoulders are joined, the label is attached, the sleeves are closed and joined. To obtain the data of each activity time, we used a representative sample of 100 data. For the calculations, the acceptable confidence level for studying this type of variable is $95 \%$.

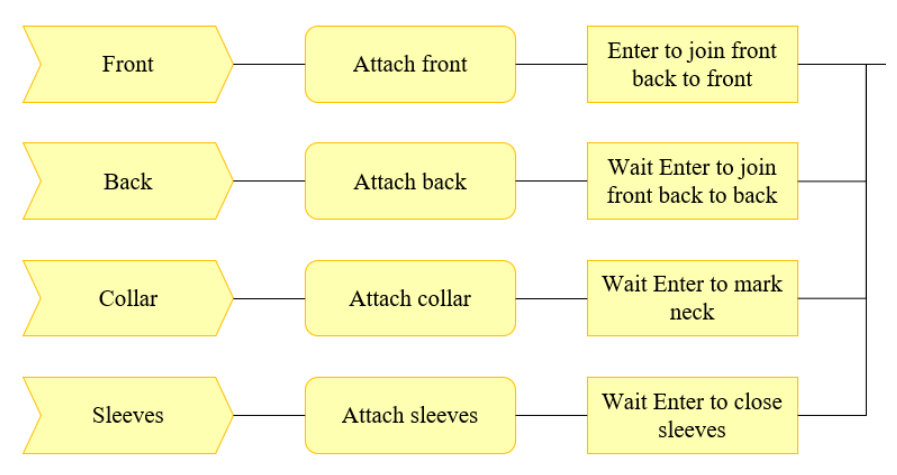

Fig. 10 simulation

To simulate the process, we used the collected data that was entered into the INPUT ANALYZER software, based on which we achieved the distribution and started the simulation. The results of the current state, as well as those obtained from the Arena software simulation are shown in Table II.

TABLE II

INDICATORS

\begin{tabular}{|l|c|c|c|}
\hline Indicator & Current & Improvement & Variation \\
\hline tFinalProduction & 6653.3 & 6361.7 & $4.38 \%$ \\
\hline tTailEndJoinCollar & 276.89 & 277.77 & \\
\hline tTailEndMarkCollar & 128.32 & 131.17 & \\
\hline tTailEndJoinBack & 104.12 & 102.64 & $1.42 \%$ \\
\hline
\end{tabular}

By implementing the improvements in the case study and simulating the standardized process in Arena, we showed the improvements achieved for the company, namely a reduction in the manufacturing cycle time of 300 seconds.
TABLE III

TRAFFIC LIGHTS INDICATORS

\begin{tabular}{|c|c|c|c|c|c|}
\hline Indicator & Level & $\begin{array}{c}\text { Formula } \\
\mathrm{N}^{\circ}\end{array}$ & $\begin{array}{l}\text { Current } \\
\text { value }\end{array}$ & $\begin{array}{l}\text { Projected } \\
\text { value }\end{array}$ & $\begin{array}{l}\text { Actual } \\
\text { value }\end{array}$ \\
\hline \multirow{2}{*}{$\begin{array}{l}\text { Defective } \\
\text { products }\end{array}$} & $\begin{array}{l}>10 \% \\
\leq 5 \%\end{array}$ & \multirow[t]{2}{*}{ (1) } & \multirow[t]{2}{*}{$16 \%$} & \multirow[t]{2}{*}{$8 \%$} & \multirow[t]{2}{*}{$5 \%$} \\
\hline & $\leq 10 \%$ & & & & \\
\hline \multirow{2}{*}{$\begin{array}{l}\text { Cleanliness } \\
\text { and order }\end{array}$} & $\leq 70 \%$ & \multirow{2}{*}{ (2) } & \multirow{2}{*}{$65 \%$} & \multirow{2}{*}{$80 \%$} & \multirow{2}{*}{$83 \%$} \\
\hline & $\begin{array}{l}\geq 90 \% \\
>70 \%\end{array}$ & & & & \\
\hline \multirow{3}{*}{$\begin{array}{l}\text { Rework } \\
\text { level }\end{array}$} & $>12 \%$ & \multirow{3}{*}{ (3) } & \multirow{3}{*}{$20 \%$} & \multirow{3}{*}{$12 \%$} & \multirow{3}{*}{$8 \%$} \\
\hline & $\leq 8 \%$ & & & & \\
\hline & $\leq 10 \%$ & & & & \\
\hline
\end{tabular}

\section{CONCLUSIONS AND Future Research}

Nowadays, many companies are looking to be competitive by increasing their productivity and profitability and reducing waste in the entire process. Through this study, we concluded that regardless of the company's industry and sector, Lean tools could be applicable in any environment. This research focuses on proposals that can be replicated in all companies that seek a methodology for solving their problems to be always focused on continuous improvement.

The standardized process reduced up to 300 seconds the manufacturing process time, with the aid of handbooks and the periodical revision of the tasks performed by each operator in this process. Moreover, the quantity of defective products was reduced by $5 \%$, and this is translated into a significant increase in the on-time delivery level, as it was possible to diminish the gap between the quantity processed and the quantity ordered by customers. Further, the training allowed the staff to properly implement the 5 S's tool to the work environment.

\section{REFERENCES}

[1] «Banco Central de Reserva del Perú,» 2019. [En línea]. Available: http://www.bcrp.gob.pe/44-proyeccion-institucional/cursos.html.

[2] «DIARIO GESTIÓN,» 2017. [En línea]. Available: https://gestion.pe/noticias/pbi.

[3] «Ministerio de la Producción,» 2019. [En línea]. Available: https://www.produce.gob.pe/index.php/conas/vistas-de-causa/2019.

[4] «Wold Economic Forum,» 2018. [En línea]. Available: https://es.weforum.org/agenda/.

[5] «Superintendencia Nacional de Aduanas y de Administración Tributaria,» 2017. [En línea]. Available: http://www.sunat.gob.pe/legislacion/tupa/2017/index.html.. [Último acceso: 18 Febrero 2019].

[6] C. D. L. D. H.T.S. Caldera, «Evaluating the enablers and barriers for successful implementation of sustainable business practice in 'lean' SMEs,» International Journal of Production Economics., 2017.

[7] A.-S. K. C.-G. T. R. G. Realyvásquez-Vargas A., «Applying the Plan-DoCheck-Act (PDCA) cycle to reduce the defects in the manufacturing industry. A case study.,» Applied Sciences (Switzerland), 2018.

[8] A. P. D. N. T. Pearcea, «Implementing lean-Outcomes from SME case studies,» Operations Research Perspectives, vol. 5, pp. 94-104, 2018.

[9] Andrade, Y., Cardenas, L., Viacava, G., Raymundo, C., Dominguez, F., (2019) "Lean manufacturing model for the reduction of production times and reduction of the returns of defective items in textile industry", Advances in Intelligent Systems and Computing, 954, pp. 387-398.

[10]O. Alaskari, M. Munir y R. Pinero, «Development of a methodology to assist manufacturing SMEs in the selection of appropriate Lean tools,» International Journal of Lean Six Sigma, vol. 7, nº 1, pp. 62-84, 2016. 
[11]H. D. C. D. L. Caldera, «Evaluating the enablers and barriers for successful implementation of sustainable business practice in 'lean' SMEs,» Journal of Cleaner Production, vol. 128, pp. 557-590, 2019.

[12]S. E. A. R. M. Martínez, «Textile management enabled by lean thinking: a case study of textile SMEs,» Production Planning and Control, vol. 27, pp. 1-9, 2016.

[13]R. Baeza, «REDUTEX: a hybrid push-pull production system approach for reliable delivery time in knitting SMEs,» Production Planning and Control, vol. 27, pp. 263-279, 2015.

[14]A. A. M. S. Behnam D., «Value stream mapping approach and analytical network process to identify and prioritize production system's Mudas,» The Journal of The Textile Institute, vol. 109, pp. 64-72, 2017.

[15]M. G. M. K. Kumar DV, «Lean Tool Implementation in the Garment Industry,» FIBRES \& TEXTILES in Eastern Europe, vol. 27, nº 2, pp. 1923, 2019.

[16]S. Bragança y E. Costa, «An application of the Lean Production tool Standard Work,» Jurnal Teknologi (Sciences \& Engineering), Vols. \%1 de \%247-53, 2015

[17]L. Qing, T. Qianlin, I. Chan, H. Wei y J. Li, «Smart manufacturing standardization: Architectures, reference models and standards framework,» Computers in Industry, vol. 101, pp. 91-106, 2018.

[18]P. Marskberry, R. Rammohan y D. Vu, «A systems study on standardised work: a Toyota perspective,» International Journal of Productivity and Quality Management, vol. 7, $\mathrm{n}^{\circ}$ 3, 2011.

[19]Cruz Ramos, «Designing a plan based preventive maintenance to improve reliability in machine availability and circular in textile company wg. Sac - lima,» 2017.

[20]A.Gouiaa-Mtibaa, S.Dellagi, Z.Achour y W.Erray, «Integrated Maintenance-Quality policy with rework process under improved imperfect preventive maintenance,» Reliability Engineering \& System Safety, vol. 173, pp. 1-11, 2018.

[21]Saad M.A.Suliman y Sayed HusainJawad, «Optimization of preventive $\mathrm{m}$

[22] aintenance schedule and production lot size,» International Journal of Production Economics, vol. 137, nº 1, pp. 19-28, 2012.

[23] Kumar D. Vasanth, Mohan G. Madhan y Mohanasundaram K.M., «Lean Tool Implementation in the Garment Industry,» Fibres \& Textiles in Eastern Europe, $\mathrm{n}^{\circ}$ 134, pp. 19-23, 2019. 